\title{
Molecular Cloning, Purification, and Characterization of a Cold-Adapted Esterase from Photobacterium sp. MA1-3
}

\author{
Young-Ok Kim*, Yu Li Heo, Bo-Hye Nam, Dong-Gyun Kim, Young-Ju Jee, Sang-Jun Lee and Cheul-Min An \\ Biotechnology Research Division, National Fisheries Research and Development Institute, Busan 619-902, Korea
}

\begin{abstract}
The gene encoding an esterase from Photobacterium sp. MA1-3 was cloned in Escherichia coli using the shotgun method. The amino acid sequence deduced from the nucleotide sequence ( $948 \mathrm{bp}$ ) corresponded to a protein of 315 amino acid residues with a molecular weight of $35 \mathrm{kDa}$ and a $\mathrm{pI}$ of 6.06 . The deduced protein showed $74 \%$ and $68 \%$ amino acid sequence identities with the putative esterases from Photobacterium profundum SS9 and Photobacterium damselae, respectively. Absence of a signal peptide indicated that it was a cell-bound protein. Sequence analysis showed that the protein contained the signature G-X-S-X-G included in most serine-esterases and lipases. The MA1-3 esterase was produced in both soluble and insoluble forms when E. coli cells harboring the gene were cultured at $18^{\circ} \mathrm{C}$. The enzyme was a serine-esterase and was active against $\mathrm{C}_{2}, \mathrm{C}_{4}, \mathrm{C}_{8}$ and $\mathrm{C}_{10} p$-nitrophenyl esters. The optimum $\mathrm{pH}$ and temperature for enzyme activity were $\mathrm{pH} 8.0$ and $30^{\circ} \mathrm{C}$, respectively. Relative activity remained up to $45 \%$ even at $5^{\circ} \mathrm{C}$ with an activation energy of $7.69 \mathrm{kcal} / \mathrm{mol}$, which indicated that it was a cold-adapted enzyme. Enzyme activity was inhibited by $\mathrm{Cd}^{2+}, \mathrm{Cu}^{2+}, \mathrm{Zn}^{2+}$, and $\mathrm{Hg}^{2+}$ ions.
\end{abstract}

Keywords: Photobacterium sp., Cold-adapted esterase, Gene expression, Substrate specificity

\section{Introduction}

Lipases and esterases (glycerol ester hydrolases, E.C. 3.1.1.) are hydrolases that act on the carboxyl ester bonds present in acylglycerols to liberate organic acids and glycerol. Esterases (E.C. 3.1.1.1) differ from lipases (E.C. 3.1.1.3) mainly based on their substrate specificity and interfacial activation (Long, 1971). Lipases, which have a hydrophobic domain covering the active site, show a preference for triglycerides of long chain fatty acids, and thus have different properties to esterases, which have an acyl binding pocket (Pleiss et al., 1998). Lipases and esterases have been recognized as useful biocatalysts because of their versatility in a wide range of industrial applications, including their use in detergents or as additives in the food industry (Harwood 1989; Jaeger and Reetz 1998). Due to their wide diversity enzymatic properties, large numbers of lipases/esterases isolated from bacteria, fungi, plants, and higher animals have been reported (Jaeger et al., 1999; Schmidt and Verger, 1998; Villeneuve et al., 2000). In particular, lipases/esterases of microbial origin represent the most extensively used class of these enzymes and are attracting increasing attention due to their relative ease of production and potential applications in biotechnology (Hasan et al., 2006). Microorganisms that thrive at low temperatures produce coldadapted enzymes, which have high catalytic efficiency, generally associated with low thermal stability (Feller et al., 1996). Among these enzymes, cold-adapted lipases/esterases are useful in industrial applications as additives in laundry detergents to allow washing in cold water, the food industry, bioremediation processes, and biodiesel applications, based on their high catalytic activity at low temperature and low thermostability as well as unusual specificities (Knothe, 2005; Hasan
http://dx.doi.org/10.5657/FAS.2013.0311 (c) 5 This is an Open Access article distributed under the terms of
the Creative Commons Attribution Non-Commercial Licens
(http://creativecommons.org/licenses/by-nc/3.0/) which any medium, provided the original work is properly cited.
Received 14 August 2013; Revised 10 September 2013

Accepted 27 September 2013

*Corresponding Author

E-mail: yobest12@korea.kr 
et al., 2006; Margesin, 2007). In addition, these enzymes can potentially be used as catalysts in organic synthesis of chiral intermediates, allowing relatively unstable compounds to be produced at low temperatures (Ryu et al., 2006). Compared to other lipases, few cold-adapted lipase/esterase have been studied. These include the enzymes from Moraxella sp. strain TA144 (Feller et al., 1991), Aeromonas sp. LPB4 (Lee et al., 2003), Pseudomonas sp. strain B11-1 (Choo et al., 1998), Acinetobacter sp. No. 6 (Suzuki et al., 2001, 2002a, 2002b), Psychrobacter sp. Ant300 (Kulakova et al., 2004), Photobacterium sp. (Ryu et al., 2006), Salinisphaera sp. P7-4 (Kim et al., 2011), and Shewanella sp. Ke75 (Kim et al., 2013).

The strain Photobacterium sp. MA1-3, previously isolated from the intestine of a blood clam, possesses a cold-adapted lipase (Kim et al., 2012). Recently, we isolated another recombinant clone bearing lipolytic activity from a gene library from this strain, and the gene was heterologously expressed in Escherichia coli cells. Here, we report the cloning, sequencing, and biochemical properties of the cloned enzyme.

\section{Materials and Methods}

\section{Materials}

Tributyrin, $p$-nitrophenyl ( $p$-NP) acetate $\left(\mathrm{C}_{2}\right)$, butyrate $\left(\mathrm{C}_{4}\right)$, caprylate $\left(\mathrm{C}_{8}\right)$, caprate $\left(\mathrm{C}_{10}\right)$, palmitate $\left(\mathrm{C}_{16}\right)$, and stearate $\left(\mathrm{C}_{18}\right)$ were purchased from Sigma (St. Louis, MO, USA), and $p$-NP myristate $\left(\mathrm{C}_{14}\right)$ was from Fluka (Milwaukee, WI, USA). All other chemicals and solvents were analytical grade and are commercially available.

\section{Gene cloning and sequence analysis}

Chromosomal DNA from Photobacterium sp. MA1-3 was partially digested with Sau3AI, ligated into a pUC118-HincII vector (Takara, Kyoto, Japan), and used to transform E. coli XL1-Blue. A colony, forming a clear halo on a Luria Bertani (LB) plate containing tributyrin and ampicillin $(100 \mu \mathrm{g} / \mathrm{mL})$, was selected. The recombinant plasmid (pUCMA1-3) was then purified from the transformant, and the insert DNA sequence was determined. DNA sequencing was performed with an Applied Biosystems Automated DNA Sequencer model 3130 with a dye-labeled terminator sequencing kit (Applied Biosystems, Foster City, CA, USA). Sequence analysis and database similarity searches were performed using the server at the National Center for Biotechnology Information (NCBI) (http://www.ncbi.nlm.nih.gov/BLAST/). Multiple sequence alignments were performed using ClustalW (Thompson et al., 1994), and the signal peptide sequence was deduced by SignalP version 3.0.

\section{Construction of the expression vector and over- expression}

The DNA corresponding to the coding region was amplified by PCR. The putative MA1-3 esterase gene was amplified from the pUCMA1-3 plasmid using the primers: 5'-TTCATATGGATAGTTGGCGCAATAGG -3' (NdeI adaptor restriction enzyme site is underlined) and $5^{\prime}$-TTCTCGAGGCTAGCTTCTTTATGTTC-3' (XhoI). After digestion with $N d e I$ and $X h o I$, the PCR product was ligated into the pET22b $(+)$ vector (Novagen, Madison, WI, USA). The resulting recombinant plasmid, pETMA1-3, was transformed into $E$. coli BL21 (DE3) cells.

\section{Purification of the recombinant protein}

E. coli BL21 (DE3) cells transformed with pETMA1-3 were cultivated in LB medium containing ampicillin (100 $\mu \mathrm{g} / \mathrm{mL}$ ) at $30^{\circ} \mathrm{C}$. When the optical density at $600 \mathrm{~nm}$ reached 0.6, $1 \mathrm{mM}$ isopropylthiogalactoside (IPTG) was added, and the cultures were further incubated overnight at $18^{\circ} \mathrm{C}$. E. coli cells were then harvested and ruptured by ultrasonic cell lysis. The soluble proteins were recovered from the cell extract by centrifugation $(10,000 \mathrm{~g}, 20 \mathrm{~min})$ and loaded onto a nickelnitrilotriacetic (Ni-NTA) column. After washing with $60 \mathrm{mM}$ imidazole, $500 \mathrm{mM} \mathrm{NaCl}$, and $50 \mathrm{mM}$ Tris- $\mathrm{HCl}$ buffer $(\mathrm{pH}$ 7.9), the bound esterase was then eluted using $1000 \mathrm{mM}$ imidazole, $500 \mathrm{mM} \mathrm{NaCl}, 20 \mathrm{mM}$ Tris- $\mathrm{HCl}$ buffer ( $\mathrm{pH}$ 7.9) and dialyzed against a $50 \mathrm{mM}$ Tris- $\mathrm{HCl}$ buffer ( $\mathrm{pH} 8.0)$ to characterize its biochemical properties. The protein concentration was determined by the BCA method with bovine serum albumin as the standard (Sigma).

\section{Esterase assay}

Esterase activity was measured using $p$-nitrophenyl ( $p$ NP) esters with fatty-acid chain lengths of $\mathrm{C}_{2}-\mathrm{C}_{18}$ (Ryu et al., 2006). The standard assay mixture $(1.0 \mathrm{ml})$ contained $10 \mathrm{mM}$ p-NP butyrate $\left(\mathrm{C}_{4}\right)$ in ethanol, $50 \mathrm{mM}$ Tris- $\mathrm{HCl}$ buffer, $\mathrm{pH} 8.0$, and $10 \mu \mathrm{l}$ of purified enzyme. Blank reactions were also run with a composition identical to the assay mixture without the enzyme. The mixture was incubated at $30^{\circ} \mathrm{C}$ for $5 \mathrm{~min}$ and the absorbance of $p$-NP librated was then measured at $405 \mathrm{~nm}$. For long-chain $p$-nitrophenyl esters $\left(\mathrm{C}_{12}-\mathrm{C}_{18}\right), 20 \mu$ l of esterase solution was added to $880 \mu \mathrm{L}$ of reaction buffer containing 50 $\mathrm{mM}$ Tris- $\mathrm{HCl}$ ( $\mathrm{pH} 8.0$ ), 0.1\% gum Arabic, and $0.2 \%$ deoxycholate. After 5 -min incubation at $30^{\circ} \mathrm{C}$, the reaction was initiated by adding $100 \mu \mathrm{l}$ of $8 \mathrm{mM}$ substrate in isopropanol. The reaction was stopped by addition of $0.5 \mathrm{ml}$ of $3 \mathrm{M} \mathrm{HCl}$. After centrifugation, $333 \mu$ of supernatant was mixed with $1 \mathrm{ml}$ of $2 \mathrm{M} \mathrm{NaOH}$, and the absorbance at $405 \mathrm{~nm}$ was measured. One unit of enzyme activity was defined as the release of $1 \mu \mathrm{mol}$ of $p$-nitrophenol per min from $p$-NP ester. 


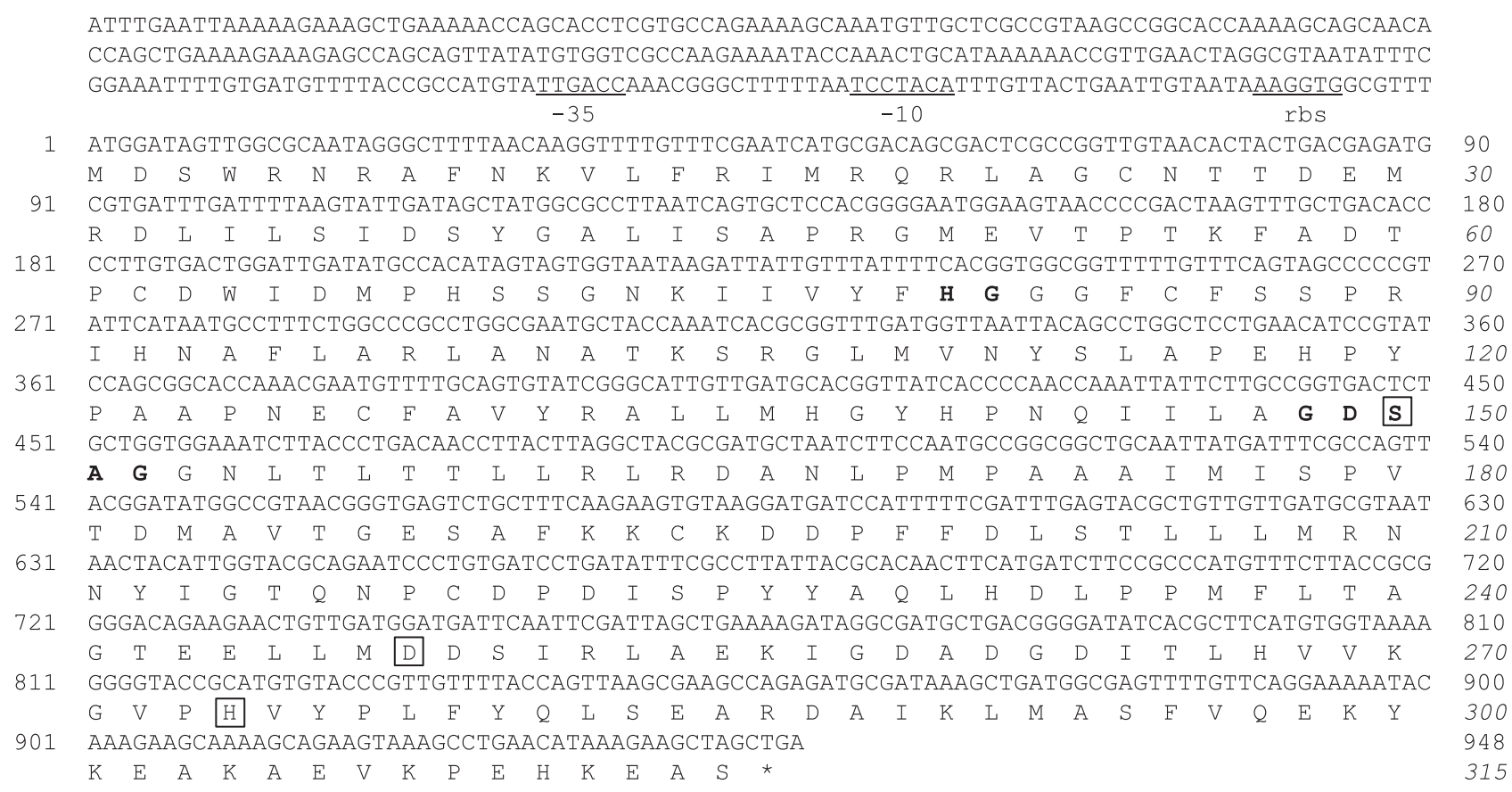

Fig. 1. Nucleotide sequence of the MA1-3 esterase gene and its deduced amino acid sequence. Potential promoter regions (-10, -35$)$ and ribosomal binding-site (RBS) are labeled and underlined. The conserved Ser, Asp, and His residues that comprise a putative catalytic triad are boxed. Both conserved pentapeptide sequence (Gly-X-Ser-X-Gly) and HG sequence (oxyanion hole) are indicated in bold. The sequence has been submitted to GenBank under accession number KF431955.

\section{Biochemical properties of recombinant esterase}

The optimum temperature was assayed at various temperatures in the range of $5-80^{\circ} \mathrm{C}$ at $50 \mathrm{mM}$ Tris- $\mathrm{HCl}(\mathrm{pH} \mathrm{8.0)}$. For thermostability, the enzyme was preincubated at various temperatures for $30 \mathrm{~min}$ in $50 \mathrm{mM}$ Tris- $\mathrm{HCl}$ buffer ( $\mathrm{pH} 8.0$ ). After rapid centrifugation, they were removed and the residual enzyme activity of the supernatant was measured as standard assay. Various buffers were used to study the effects of $\mathrm{pH}$ : sodium acetate/acetic acid ( $\mathrm{pH} 4-6)$, Tris/acetate ( $\mathrm{pH}$ 6-7), Tris/ $\mathrm{HCl}$ ( $\mathrm{pH}$ 7-9), and sodium tetraborate/ $\mathrm{NaOH}(\mathrm{pH} 9-11)$. To determine $\mathrm{pH}$ stability, the enzyme was preincubated at $25^{\circ} \mathrm{C}$ in buffers of various $\mathrm{pH}$ for $1 \mathrm{~h}$ and the remaining activity was measured by standard assay. The effects of various metal ions and inhibitors on enzyme activity were assessed after preincubation in $50 \mathrm{mM}$ Tris- $\mathrm{HCl}$ buffer $(\mathrm{pH} 8.0)$ at $25^{\circ} \mathrm{C}$ for 30 min. Blank reactions were performed with each measurement under different conditions and the values for nonenzymatic hydrolysis of substrates were subtracted from the results.

\section{GenBank accession number}

The nucleotide sequence of the Photobacterium sp. MA13 esterase gene has been deposited in the GenBank database under accession number KF431955.

\section{Results and Discussion}

\section{Gene cloning and sequence analysis}

A DNA library of Photobacterium sp. MA1-3 was constructed with the Sau3A1 enzyme and used to transform $E$. coli XL1-Blue. E. coli transformant that showed a clear zone on TBN-LB plates after $48 \mathrm{~h}$ of incubation were selected. The recombinant plasmid from a clone was shown to contain a DNA insert of $3.2 \mathrm{~kb}$, with one complete open reading frame (ORF) corresponding to a putative esterase/lipase gene based on the results of a homology search. The complete DNA sequence of the MA1-3 esterase was determined (Fig. 1). It contained a ORF of $948 \mathrm{bp}$, encoding a polypeptide chain of 315 amino acids with a predicted molecular weight of 35,020 and a pI value of 6.06. No signal sequence was found, as determined by SignalP version 3.0, suggesting that the MA1-3 esterase is a cell-bound protein. A putative ribosomal binding-site (RBS) was located 5 bp upstream of the MA1-3 esterase. In addition, a putative transcriptional initiation site with a -10 region was located 32 bp upstream of the MA1-3 esterase start codon and separated from the -35 region by $15 \mathrm{bp}$. The predicted amino acid sequence of the cloned MA1-3 esterase was compared with other protein sequences deposited in GenBank using the basic local alignment search tool (BLAST) program (Fig. 2A). The esterase showed $74 \%, 68 \%, 52 \%$, and $36 \%$ identities with 


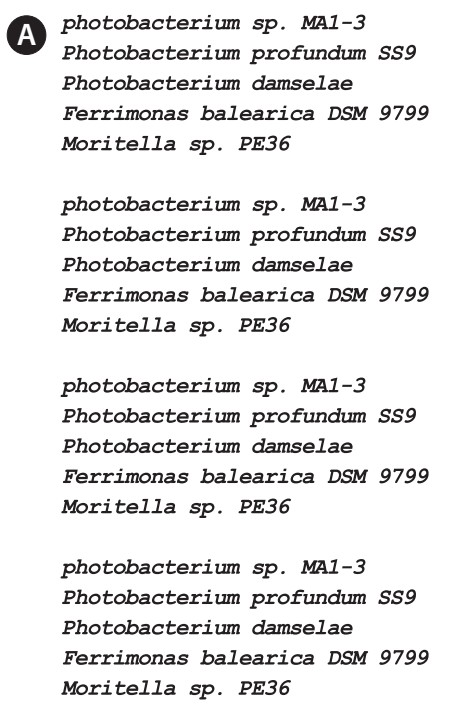

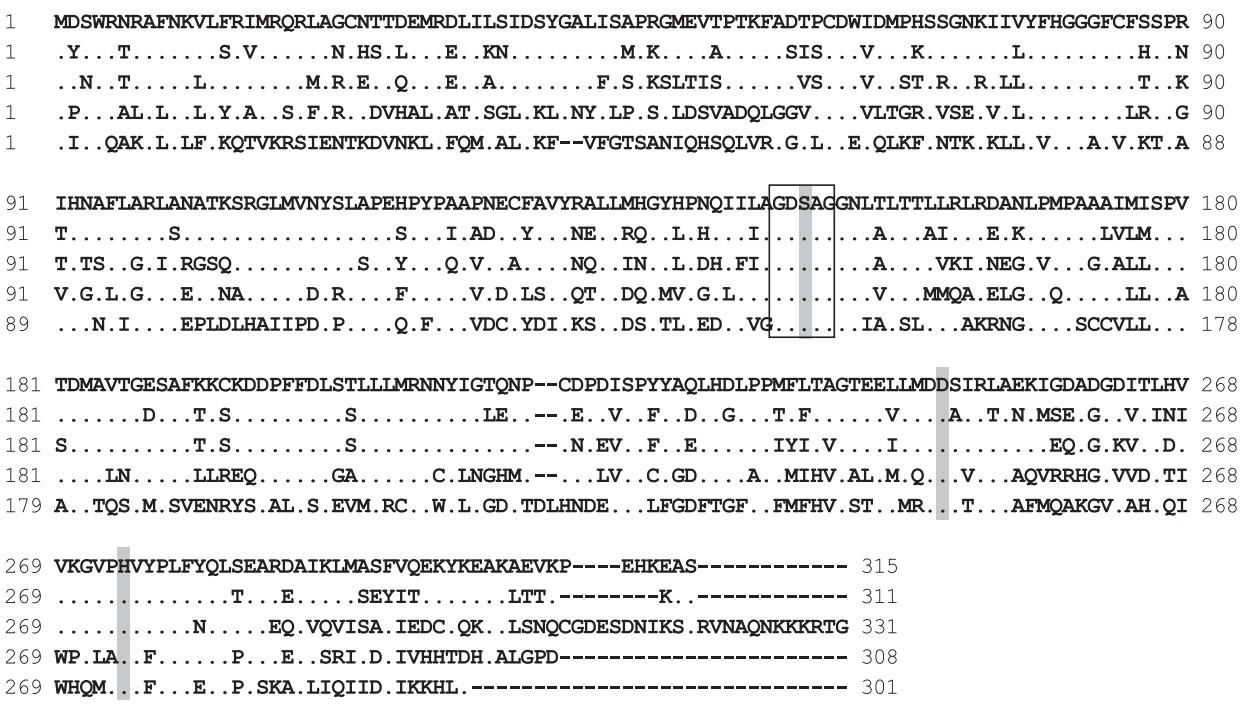

B

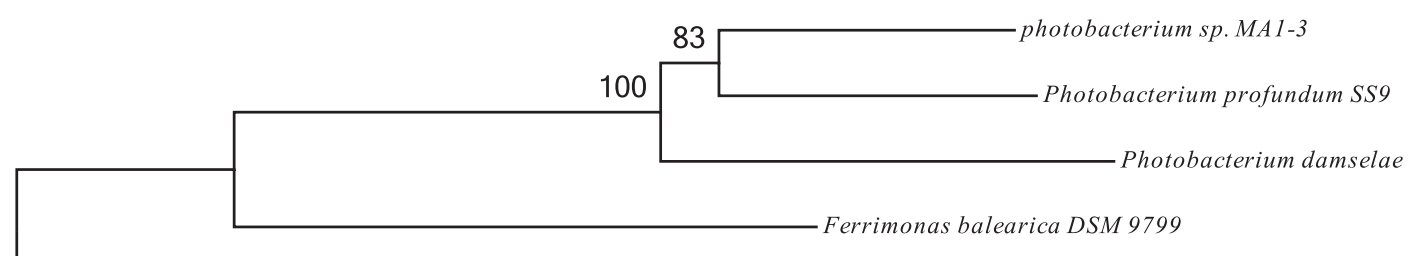

Moritella sp. PE36

0.1

Fig. 2. Protein sequence alignment (A) and phylogenetic tree (B) of MA1-3 esterase and five similar enzymes. (A) Identity sequences are displayed by dots (...), and deletions of amino acid residues are indicated by dashes (---). Residues involved in the catalytic triad are shaded. Conserved pentapeptide containing the catalytic serine is shown in box. The accession numbers for each sequence are as follows: Photobacterium sp. MA1-3 (KF431955), Photobacterium profundum SS9 (YP_130084), Photobacterium damselae (WP_005299527), Ferrimonas balearica (YP_003912034), Moritella sp. PE36 (WP_006032431). (B) A phylogenetic tree of the aligned sequences was constructed using the Neighbor-Joining algorithm in MEGA (version 4.0). The degree of confidence for each branch point was determined by bootstrap analysis (1,000 repetitions).

the putative esterase/lipases from Photobacterium profundum SS9, Photobacterium damselae, Ferrimonas balearica, and Moritella sp. PE36, respectively. The MA1-3 esterase was only $44 \%$ identical to the lipases of the same strain Photobacterium sp. MA1-3 (Kim et al., 2012).

The MA1-3 esterase primary structure contained a -G-DS-A-G- sequence (positions 148-152), which corresponds well with the pentapeptide -G-x-S-x-G- signature motif that is generally conserved in many esterase enzymes. Based on sequence comparisons with other esterases, it was concluded that Ser 150 (in the motif GDSAG), Asp 248, and His 274 comprise the catalytic triad. Finally, an HG sequence (His80, Gly81), which constitutes an oxyanion hole in the three-dimensional protein structure, was found in the esterase (Grochulski et al., 1993; Martinez et al., 1994). Sequence analysis suggested that MA1-3 esterase may be a functional esterase with a novel amino acid sequence.
Fig. 2B shows the phylogenetic tree, indicating the evolutionary relationship with other bacterial esterases based on the amino acid sequence. The phylogram generated using Phylip showed that Photobacterium sp. MA1-3 esterase was more closely related to a putative esterase from Photobacterium profundum SS9 than to other lipases and esterases identified to date.

\section{Expression and identification of the recombinant esterase}

E. coli BL21 (DE3) was transformed with the plasmid, pETMA1-3, and was induced to express the recombinant protein using $1 \mathrm{mM}$ IPTG. When cultivated and incubated at $37^{\circ} \mathrm{C}$, the resulting protein was insoluble; however, at the lower culture temperature of $18^{\circ} \mathrm{C}$, the resulting protein was both soluble and insoluble (Fig. 3). Approximately $20 \%$ of the 


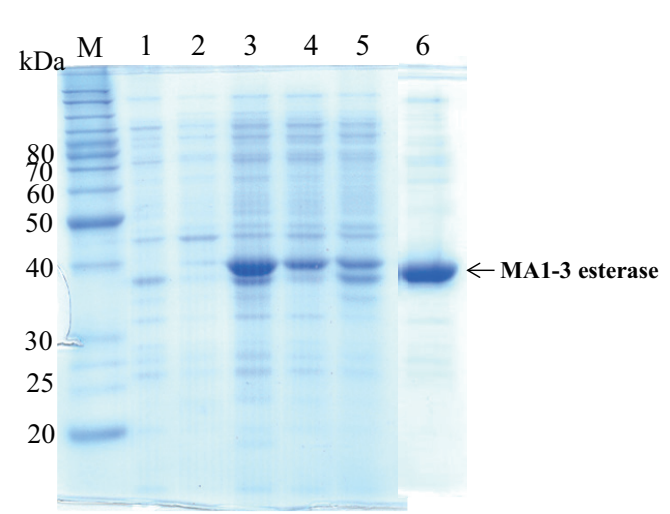

Fig. 3. Sodium dodecyl sulfate (SDS)-polyacrylamide gel electrophoresis (PAGE) of MA1-3 esterase. Lane M, Standard protein molecular weight markers; lane 1, lysate supernatants of uninduced transformant; lane 2 and 3 , soluble and insoluble protein induced by isopropylthiogalactoside (IPTG) at $37^{\circ} \mathrm{C}$; lane 4 and 5 , soluble and insoluble protein induced by IPTG at $18^{\circ} \mathrm{C}$ lane 6 , purified esterase by nickel-nitrilotriacetic (Ni-NTA) affinity column chromatography. Arrow indicates MA1-3 esterase.

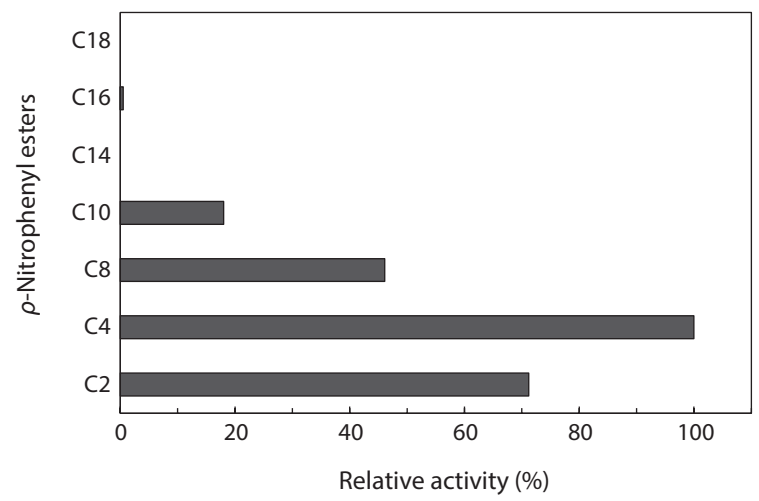

Fig. 4. Substrate specificity of MA1-3 esterase. Hydrolysis activity was measured toward various $p$-nitrophenyl esters.

recombinant esterase protein was produced in soluble form in $E$. coli cells. The recombinant enzyme was then purified to homogeneity by His-Bind resin affinity chromatography with a six-histidine tag at the $\mathrm{C}$-terminus. Sodium dodecyl sulfatepolyacrylamide gel electrophoresis analysis of the eluted fraction showed a distinctly expressed protein band of $39 \mathrm{kDa}$ (Fig. 3). This mass is in agreement with the mass of the esterase $(35 \mathrm{kDa})$ with an additional 36 amino acid residues corresponding to the $\mathrm{N}$-terminus $6 \times$ histidine-tag and the linker region. The specific activity of the purified enzyme was 20.2 $\mathrm{U} / \mathrm{mg}$ toward $p$ - $\mathrm{NP}$ butyrate at $30^{\circ} \mathrm{C}$. Its activity was 3.8 - and 2.9-fold higher than those of PWTSB and PWTSC, which had specific activities of 5.3 and $6.9 \mathrm{U} / \mathrm{mg}$ toward PNPB, respectively (Wei et al., 2009). In contrast, Ke75 esterase showed a lightly higher specific activity of $22.75 \mathrm{U} / \mathrm{mg}$ (Kim et al., 2013).

\section{Substrate specificity}

The substrate specificity of MA1-3 esterase was examined with various $p$-NP esters with aliphatic acyl-chains of different lengths from 2 to 18 carbon atoms (Fig. 4). Analysis of the enzyme hydrolytic activity against these $p$-NP esters showed a strong preference toward short acyl chains of $p$-NP-2, $p$-NP-4 and $p$-NP- 8 esters, with $p$-NP- $\mathrm{C}_{4}$ being the most easily hydrolyzed substrate. The reactivities of these substrates to the enzyme were dependent on their acyl-chain length, and the substrates with $\mathrm{C}_{14}, \mathrm{C}_{16}$, and $\mathrm{C}_{18}$ acyl groups were virtually inert as substrates for the enzyme. Based on the substrate preference profile, MA1-3 esterase was classified as a true carboxylesterase (Jaeger et al., 1993, 1999; Bornscheuer, 2002).

\section{Effects of pH and temperature on enzyme activity and stability}

The temperature activity profile of MA1-3 esterase was examined over the temperature range of $5-80^{\circ} \mathrm{C}$ under assay conditions with $p$-NP butyrate as the substrate (Fig. 5A). Enzyme activity peaked at $30^{\circ} \mathrm{C}$. The activation energy of the enzymes derived from cold-active organisms is usually lower than those from their mesophilic counterparts (Feller et al., 1996). As expected, the activation energy of MA1-3 esterase was $7.69 \mathrm{kcal} / \mathrm{mol}$ in the range of $5^{\circ} \mathrm{C}$ to $30^{\circ} \mathrm{C}$, which is lower than those of other cold-adapted esterases: $11.2 \mathrm{kcal} / \mathrm{mol}$ for the esterase of Pseudomonas sp.B11-1 (Suzuki et al., 2003); $9.0 \mathrm{kcal} / \mathrm{mol}$ for the esterase of Acinetobacter sp. No. 6 (Suzuki et al., 2002a); and $11.25 \mathrm{kcal} / \mathrm{mol}$ for the esterase of Acinetobacter lwoffii 16C-1 (Kim and Park, 2002). These observations suggest that the catalytic efficiency of this esterase is high over this temperature range. In fact, this esterase showed as much as $45 \%$ of the maximum activity at $5{ }^{\circ} \mathrm{C}$. The enzyme was stable within the temperature range $5 \sim 40^{\circ} \mathrm{C}$. However, it was thermally unstable and lost its activity at temperatures above $50^{\circ} \mathrm{C}$ (Fig. 5C). Taken together, these observations indicated that MA1-3 esterase is a typical cold-adapted enzyme

The optimal $\mathrm{pH}$ of MA1-3 esterase was determined to be 8.0 , and it retained at least $80 \%$ of its maximum activity between $\mathrm{pH} 8.0$ and 9.0, indicating that it is an alkaline enzyme (Fig. 5D). Although its esterase activity was somewhat different depending on the various incubation buffers used, the MA1-3 esterase was fairly stable after incubation in buffers ranging in $\mathrm{pH}$ from 7.0 to 10.0 (Fig. 5E). The maximum activity at alkaline $\mathrm{pH}$ is a useful characteristic for detergent applications.

\section{Effects of metal ions and inhibitors on esterase activity}

The effects of various metal ions and inhibitors on enzyme activity were determined (Table 1). Divalent salts, such as $\mathrm{MgCl}_{2}$, simulated the esterase activity to $119 \%$ compared to 

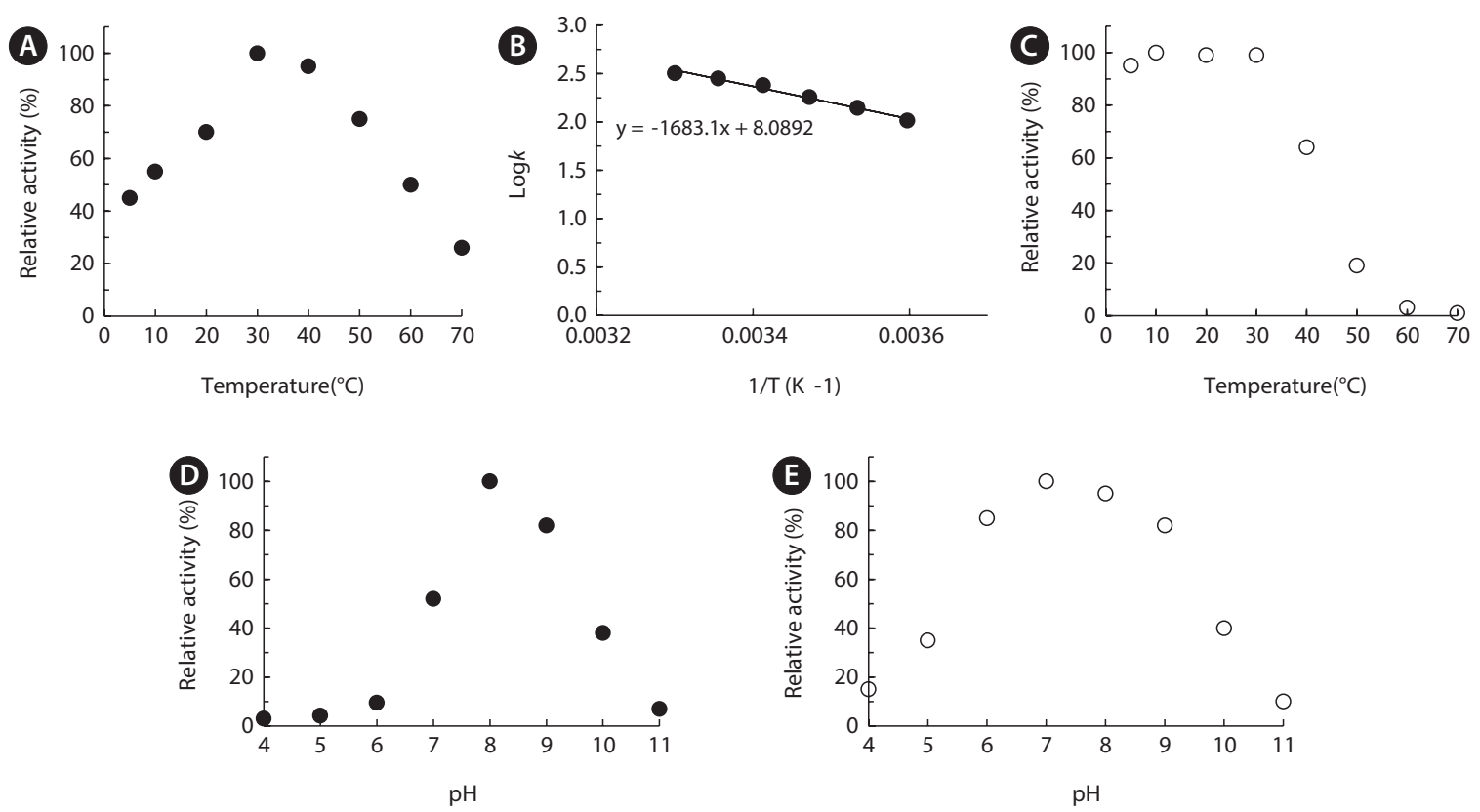

Fig. 5. Effects of temperature and $\mathrm{pH}$ on the activity and stability of MA1-3 esterase. (A) Hydrolytic activity was assayed at various temperatures (B) The logarithm of the enzyme turnover rate $(\mathrm{k})\left(\mathrm{s}^{-1}\right)$ was plotted against the reciprocal of absolute temperature (T). The values shown are activation energy calculated from the linear part of the Arrhenius plot. (C) Residual hydrolytic activity was measured after treatment for 30 min at a range temperatures (D) Hydrolytic activity was assayed at various pHs (E) Residual hydrolytic activity was measured after treatment for $30 \mathrm{~min}$ at a range $\mathrm{pH}$ values.

control, whereas the activity was decreased by $50 \sim 60 \%$ in the presence of $\mathrm{MnSO}_{4} \mathrm{NiSO}_{4}$, and $\mathrm{CoCl}_{2}$ Moreover, its activity was strongly inhibited by $5 \mathrm{mM}$ metal ions such as $\mathrm{CdCl}_{2}$, $\mathrm{CuCl}_{2}, \mathrm{ZnCl}_{2}$, and $\mathrm{HgCl}_{2}$.

To confirm that the enzyme was a serine hydrolase, the activity of MA1-3 esterase was determined in the presence of 1 $\mathrm{mM}$ phenylmethylsulfonyl fluoride (PMSF), a catalytic serine enzyme inhibitor. Similar concentrations of a metal-chelating

Table 1. Effects of various metal ions and inhibitors on MA1-3esterase activity

\begin{tabular}{|c|c|}
\hline Metal ions or reagents $(5 \mathrm{mM})$ & Relative activity (\%) \\
\hline $\mathrm{CaCl}_{2}$ & $63 \pm 4.2$ \\
\hline $\mathrm{CdCl}_{2}$ & $1 \pm 0.8$ \\
\hline $\mathrm{CuSO}_{4}$ & $6 \pm 2.1$ \\
\hline $\mathrm{CoCl}_{2}$ & $39 \pm 1.7$ \\
\hline $\mathrm{FeSO}_{4}$ & $95 \pm 2.5$ \\
\hline $\mathrm{HgCl}_{2}$ & $2 \pm 1.3$ \\
\hline $\mathrm{KCl}$ & $99 \pm 4.2$ \\
\hline $\mathrm{MgCl}_{2}$ & $119 \pm 0.4$ \\
\hline $\mathrm{MnSO}_{4}$ & $60 \pm 1.5$ \\
\hline $\mathrm{NiSO}_{4}$ & $54 \pm 3.7$ \\
\hline $\mathrm{ZnCl}_{2}$ & $4 \pm 2.3$ \\
\hline EDTA & $105 \pm 0.6$ \\
\hline PMSF & $3 \pm 1.1$ \\
\hline DTT & $102 \pm 1.6$ \\
\hline
\end{tabular}

"Data are presented \pm standard deviation. agent, ethylenediaminetetraacetic acid (EDTA), and a reducing agent, dithiothreitol (DTT), were also investigated to eliminate the possible involvement of metal cations or cysteine in the enzyme mechanism. MA1-3 esterase was significantly inhibited $(98 \%)$ by PMSF, while the other two additives (DTT and EDTA) had little effect on its activity. The inhibitory effect of PMSF on MA1-3 esterase indicated the involvement of serine-mediated catalytic activity in this enzyme.

In this study, a novel esterase produced by Photobacterium sp. MA1-3 exhibited high activity at low temperatures and alkaline $\mathrm{pH}$. Its low activation energy in the range of $5-30^{\circ} \mathrm{C}$ indicated that it is a cold-adapted enzyme. These results suggest that this enzyme may be useful as a biocatalyst and detergent additive for low temperature applications.

\section{Acknowledgements}

This work was supported by a grant from the National Fisheries Research and Development Institute (NFRDI), Republic of Korea.

\section{References}

Bornscheuer UT. 2002. Microbial carboxylesterases: classification, properties and applications in biocatalysis. FEMS Microbiol Rev 26, 73-81. http://dx.doi.org/10.1016/S0168-6445(01)00075-4. 
Choo DW, Kurihara T, Suzuki T, Soda K, and Esaki N. 1998. A coldadapted lipase of an alaskan psychrotroph, Pseudomonas sp. strain B11-1: gene cloning and enzyme purification and characterization. Appl Environ Microbiol 64, 486-491.

Feller G, Thiry M, and Gerday C. 1991. Nucleotide sequence of the lipase gene Lip2 from the antarctic psychrotroph Moraxella TA144 and site-specific mutagenesis of the conserved serine and histidine residues. DNA Cell Biol 10, 381-388.

Feller G, Narinx E, Arpigny JL, Aittaleb M, Baise E, Geniot S and Gerday C. 1996. Enzymes from psychrophilic organisms. FEMS Microbiol Rev 18, 189-202. http://dx.doi.org/10.1016/01686445(96)00011-3.

Grochulski P, Li Y, Schrag JD, Bouthillier F, Smith P, Harrison D, Rubin B and Cygler M. 1993. Insights into interfacial activation from an open structure of Candida rugosa lipase. J Biol Chem 268, 12843-12847.

Harwood J. 1989. The versatility of lipases for industrial uses. Trends Biochem Sci 14, 125-126. http://dx.doi.org/10.1016/0968-0004(89) 90140-0.

Hasan F, Shah AA and Hameed A. 2006. Industrial applications of microbial lipases. Enzyme Microb Technol 39, 235-251. http:// dx.doi.org/10.1016/j.enzmictec.2005.10.016.

Jaeger KE and Reetz MT. 1998. Microbial lipases from versatile tools for biotechnology, Trends Biotechnol 16, 396-403. http://dx.doi. org/10.1016/S0167-7799(98)01195-0.

Jaeger KE, Ransac S, Koch HB, Ferrato F and Dijkstra BW. 1993. Topological characterization and modeling of the 3D structure of lipase from Pseudomonas aeruginosa. FEBS Lett 332, 143-149. http:// dx.doi.org/10.1016/0014-5793(93)80501-K.

Jaeger KE, Dijkstra BW and Reetz MT. 1999. Bacterial biocatalysts: molecular biology, three-dimensional structures, and biotechnological applications of lipases. Annu Rev Microbiol 53, 315-351. http://dx.doi.org/10.1146/annurev.micro.53.1.315.

Kim HE and Park KR. 2002. Purification and characterization of an esterase from Acinetobacter lwoffii 16C-1. Curr Microbiol 44, 401405. http://dx.doi.org/10.1007/s00284-001-0008-6.

Kim YO, Park IS, Kim HK, Nam BH, Kong HJ, Kim WJ, Kim DG, Kim KK and Lee SJ. 2011. A novel cold-adapted esterase from Salinisphaera sp. P7-4: gene cloning, overexpression, and characterization. J Gen Appl Microbiol 57, 357-364.

Kim YO, Khosasih V, Nam BH, Lee SJ, Suwanto A, Kim HK. 2012. Gene cloning and catalytic characterization of cold-adapted lipase of Photobacterium sp. MA1-3 isolated from blood clam. J Biosci Bioeng 114, 589-595.

Kim YO, Park IS, Kim HK, Nam BH, Kong HJ, Kim WJ, Kim DG, Kim BS, Jee YJ, Song JH and Lee SJ. 2013. Shewanella sp. Ke75 esterase with specificity for $p$-nitrophenyl butyrate: gene cloning and characterization. 56, 55-62. http://dx.doi.org/10.1007/s13765012-2089-2.

Knothe G. 2005. Dependence of biodiesel fuel properties on the structure of fatty acid alkyl esters. Fuel Process Technol 86, 1059-1070. http://dx.doi.org/10.1016/j.fuproc.2004.11.002.

Kulakova L, Galkin A, Nakayama T. Nishino T and Esaki N. 2004. Cold-active esterase form Psychrobacter sp. Ant300: gene cloning, characterization, and the effects of Gly $\rightarrow$ Pro substitution near the active site on its catalytic activity and stability. Biochim Biophys Acta 1696, 59-65. http://dx.doi.org/10.1016/j.bbapap.2003.09.008.

Lee HK, Ahn MJ, Kwak SH, Song WH and Jeong BC. 2003. Purification and characterization of cold active lipase from psychrotrophic Aeromonas sp. LPB4. J Microbiol 41, 22-27.

Long C. 1971. Biochemists Handbook. Redwood, London, GB, pp 273274.

Margesin R. 2007. Alpine microorganisms: useful tools for low-temperature bioremediation. J Microbiol 45, 281-285.

Martinez C, Nicolas A, van Tilbeurgh H, Egloff MP, Cudrey C, Verger R and Cambillau C. 1994. Cutinase, a lipolytic enzyme with a preformed oxyanion hole. Biochemistry 33, 83-89. http://dx.doi. org/10.1021/bi00167a011.

Pleiss J, Fischer M and Schmid RD. 1998. Anatomy of lipase binding sites: the scissile fatty acid binding site. Chem Phys Lipids 93, 6780. http://dx.doi.org/10.1016/S0009-3084(98)00030-9.

Ryu HS, Kim HK, Choi WC, Kim MH, Park SY, Han NS, Oh TK and Lee JK. 2006. New cold-adapted lipase from Photobacterium lipolyticum sp. nov. that is closely related to filamentous fungal lipases. Appl Microbiol Biotechnol 70, 321-326. http://dx.doi.org/10.1007/ s00253-005-0058-y.

Schmid RD and Verger R. 1998. Lipases; interfacial enzymes with attractive applications. Angew Chem Int Ed 37, 1608-1633. http://dx.doi. org/10.1002/(SICI)1521-3773(19980703)37:12<1608::AIDANIE1608>3.3.CO;2-M.

Suzuki T, Nakayama T, Kurihara T, Nishino T and Esaki N. 2001. Coldactive lipolytic activity of psychrotrophic Acinetobacter sp. strain no. 6. J Biosci Bioeng 92, 144-148. http://dx.doi.org/10.1263/ jbb.92.144.

Suzuki T, Nakayama T, Kurihara T, Nishino T, and Esaki N. 2002a. A cold-active esterase with a substrate preference for vinyl esters from a psychrotroph, Acinetobacter sp. strain no. 6: gene cloning, purification, and characterization. J Mol Catal B Enzym 16, 255263. http://dx.doi.org/10.1016/S1381-1177(01)00070-4.

Suzuki T, Nakayama T, Kurihara T, Nishino T and Esaki N. 2002b. Primary structure and catalytic properties of a cold-active esterase from a psychrotroph, Acinetobacter sp. strain no. 6 isolated from Siberian soil. Biosci Biotechnol Biochem 66, 1682-1690. http:// dx.doi.org/10.1271/bbb.66.1682.

Suzuki, T, Nakayama T, Choo DW, Hirano Y, Kurihara T, Nishino T and Esaki N. 2003. Cloning, heterologous expression, renaturation, and characterization of a cold-adapted esterase with unique primary structure from a psychrotroph Pseudomonas sp. strain B11-1. Protein Expr Purif 30, 171-178. http://dx.doi.org/10.1016/S10465928(03)00128-1.

Thompson JD, Higgins DG and Gibson TJ. 1994. CLUSTAL W: improving the sensitivity of progressive multiple sequence alignment through sequence weighting, positions-specific gap penalties and weight matrix choice. Nucleic Acids Res 22, 4673-4680. http:// dx.doi.org/10.1093/nar/22.22.4673.

Villeneuve P, Muderhwa JM, Graille J and Haas MJ. 2000. Customizing lipases for biocatalysis: a survey of chemical, physical and molecular biological approaches. J. Mol. Catal B: Enzym 9, 113-148. 
Fish Aquat Sci 16(4), 311-318, 2013

http://dx.doi.org/10.1016/S1381-1177(99)00107-1.

Wei P, Bai L, Song W and Hao G. 2009. Characterization of two soil metagenome-derived lipases with high specificity for $p$-nitrophenyl palmitate. Arch Microbiol 191, 233-240. http://dx.doi. org/10.1007/s00203-008-0448-5. 